\title{
CLIMATE CHANGE and DENGUE in INDONESIA: a SYSTEMATIC REVIEW
}

\author{
Fajar Fatmawati ${ }^{1}$ and Sulistyawati Sulistyawati ${ }^{1^{*}}$ \\ ${ }^{1}$ Faculty of Public Health, Universitas Ahmad Dahlan, Yogyakarta, Indonesia \\ "Correspondence: Email: sulistyawatisuyanto@gmail.com. Tel: +628170402693 \\ Received 07 August 2019; Accepted 09 September 2019; Published 09 September 2019
}

\begin{abstract}
Background: Climate change is a global issue because of its impact on environmental and human health. No exception for Indonesia, an archipelago state with a tropical climate. Climate change potentially influences the mosquitos borne disease, including dengue fever, which poses a vulnerability to the Indonesian populations. This article aims to review the association and the impact of climate change to dengue fever, particularly in Indonesia and to inform the policymaker on directing the adaptation option.
\end{abstract}

Methods: Of thirteen peer review articles were included in this review sourced from google scholar database.

Results: Climate change affects dengue incidence in Indonesia due to climate variability.

Conclusions: It is essential to Strengthen the surveillance system and provide an early warning system (EWS) based on climate information.

Keywords: Climate change, dengue, Indonesia

\section{INTRODUCTION}

Climate change which is a global phenomenon received attention from many countries due to its impact on human and environment. Global temperature surface during the decade of $2006-2015$ was $0.87^{\circ} \mathrm{C}$, and between 2030 and 2052 it has been predicted that temperature will be $1.5^{\circ} \mathrm{C}$. Consequently, the risk of climate change to health is expected to be growing (1). Temperature plays a vital role in the development, longevity, reproduction and virus transmission of mosquito (2). Climate change is suspected to aggravate the risk of mosquito-borne disease, including dengue fever. This situation is a global threat, particularly for countries in South Asia and Sub-Sahara Africa (3). 


\section{Epidemiology and Society Health Review $\mid \boldsymbol{E S H R}$}

Indonesia is a tropical climate country and archipelagic state. Accordingly, this country is easily affected by climate change such as temperature rising and climate shifting that carries some impacts such as drought and failure of harvesting. Climate change in Indonesia can be seen from the increasing of the temperature above average every year and the decreasing of annual rainfall in some regions. The South part of Indonesia tends to have less rain while the north has more rainfall, even it is always increasing (4). The temperature average in Indonesia during 1981-2010 was $27^{\circ} \mathrm{C}$. However, in May 2019, it was detected that it was increasing up to $0,9^{\circ} \mathrm{C}(5)$.

Dengue is a disease that is closely associated with the environmental condition. As a result, the changing of environment will lead to a dengue transmission pattern. Dengue case in Indonesia in the last 45 years is increasing dramatically with intermitted hyperendemic pattern (6) which affected the health of the large population. This occurrence predicted the interplay between the disease and climate variable. For example, the changing of temperature, humidity and wind speed affects the changing of the number of vector population not only for dengue but also for some other diseases such as malaria, leptospirosis and filariasis (7).

In 2017, the number of dengue case in Indonesia was decreasing significantly from the previous period by having 204.171 cases (8). However, this situation could be different in the next coming year due to the changing the environment, such as climate changes. Accordingly, a study to summarise the Indonesian situation regarding dengue and climate change is essential as a part to prepare adaptation strategy to anticipate the worst situation.

This review aims to summarize the previous research that elaborate on the relationship between climate change phenomenon and dengue incidence in Indonesia. The goal of this review is to develop an idea on an adaptation strategy to reduce dengue disease in the future.

\section{METHODS}

\section{Search Strategy}

Google and Google scholar were used as the main source of database accessed in June-July 2019 to extract studies published both in English and Bahasa Indonesia that discussed Indonesia context. A set of combination keywords: "Dengue haemorrhagic fever", "dengue fever \& climate", "weather", "climate change", "climate variability", "climatic factors", "temperature", "rainfall", "humidity", "indonesia" were used to search the article. We observed research paper published during 2014-2019. Title, keyword and abstracts were screened for the first step for the relevant article and the full paper that met our criteria inclusion, were included in our analysis.

\section{Inclusion criteria}

1. Articles must appraise the impact of climate change on dengue transmission and spread by discussing climate variables such as temperature, rainfall and humidity and disease variables such as incidence and case.

2. The article should employ epidemiology design such as actual analysis, Spatio-temporal and descriptive study for identifying the relationship between climate variable versus dengue transmission and spreading

3. The article should discuss Indonesia and published in 2014-2019 


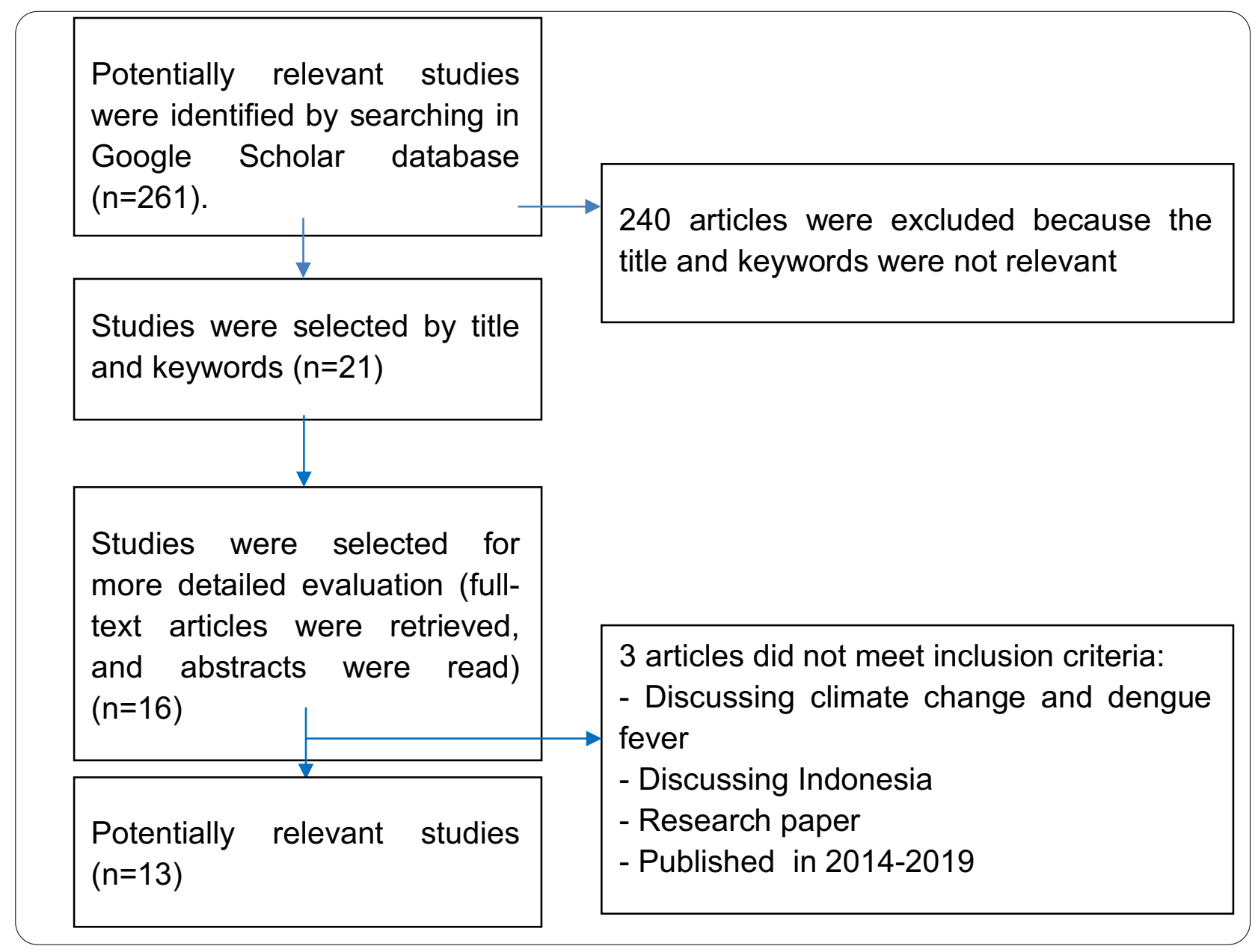

Figure 1. Flow chart of article review

\section{Results}

\section{Literature search}

Two hundred and sixty-one articles were collected from Google scholar in the first step. Among them, 240 articles were excluded since they did not meet the title and keyword, while 21 articles were included. In terms of the full paper, 16 articles were included, and at the final stage, 13 articles met our inclusion criteria. Methodology and main finding of the 13 articles are summarised in Table 1. The study took place in Sleman $(n=2)$, North Minahasa District, Ternate City, Limboto subdistrict, Jakarta City, Sulawesi Tenggara Province, Surabaya City, Medan City, Banjarmasin City, Cirebon District, Kolaka District and Indonesia.

All of the included articles were studying the association between climate variable and dengue incidence. Some methods were used to determine the relationship between the climate variable and dengue incidence. Three of them employed a descriptive study through ecologic approach (9),(13),(18). Correlation and multiple regressions (Poisson), path analysis which is an extension from linear regression also used as an approach 18. Three articles used time series (12),(16),(21), one article employed time series decomposition analysis with Loess (STL) model and one article used smoothing (19). Only one article used ecology proxy indicators such as Normalized Difference Vegetation Index (NDVI), Moran's I analysis, and LISA 


\section{Epidemiology and Society Health Review $\mid \mathbf{E S H R}$}

analysis (19). Some research elaborated the determinants such as attitude and behaviour, environmental, land cover type, and altitude (11), (14), (15). GAM model was used to express the non-linear relationship and non-monotonic between the response variable and predictor (17). Four articles reviewed the use of Geographic Information System (GIS) to create a risk map based on vector distribution (12),(17),(19),(21).

\section{DISCUSSION}

\section{Association between climate variable and dengue incidence}

In most of the endemic research location studied, climate variable was significantly correlated to dengue cases. Temperature, humidity, and rainfall were the standard variables associated with dengue incidence. To identify climate risk factor to dengue incidence in Indonesia, research had been done to seek the relationship between meteorological variable and dengue (9-21).

According to the analysis, almost all of the article reported that temperature had a correlation to dengue transmission from low to medium power. In Ternate, monthly temperature average is $24.8^{\circ} \mathrm{C}-29.0^{\circ} \mathrm{C}$. The highest temperature occurred in 2009 $\left(29^{\circ} \mathrm{C}\right)$. At that moment, dengue incidence was increasing from January, and the peak occurred in March (10). This occurrence was probably associated with mosquito longevity which is at $27^{\circ} \mathrm{C}$, so the increase of the temperature influences the dengue virus. In other areas, the temperature did not have a correlation with dengue incidence, possibly due to the low temperature in that location. Such as in Sleman-Yogyakarta, the monthly temperature average is $22,8^{\circ} \mathrm{C}-27,2^{\circ} \mathrm{C}$, meaning that it tends to be cold for the maturation of mosquito egg.

Low temperature shortens the incubation period and prolongs the mosquito reproduction cycle as well as reduces mosquito biting (22). Large differentiating temperature influences the number of female mosquitos, meaning that the number of blood-sucking mosquitoes for transmitting the virus is decreasing (11). Meanwhile, in Gamping subdistrict-Godean-Sleman District, Medan City and Kolaka District, the differences of maximum-minimum of the temperature were associated with dengue incidence (11), (17), (20). The high disparity of minimum and maximum temperature impacts on the low of dengue incidence (11). 
Table 1. Studies characteristic discussed the association between climatic variables and dengue

\begin{tabular}{|c|c|c|c|c|c|c|}
\hline \multirow[t]{2}{*}{$\begin{array}{c}\text { Study \& } \\
\text { Language }\end{array}$} & \multirow[t]{2}{*}{$\begin{array}{c}\text { Study area \& } \\
\text { period }\end{array}$} & \multicolumn{2}{|c|}{ Data Collection } & \multirow[t]{2}{*}{$\begin{array}{l}\text { Statistical } \\
\text { Methods }\end{array}$} & \multirow[t]{2}{*}{ Main findings } & \multirow[t]{2}{*}{ Comments } \\
\hline & & Risk factors & $\begin{array}{c}\text { Diseasel } \\
\text { vector }\end{array}$ & & & \\
\hline $\begin{array}{l}\text { Lasut et al. } \\
\text { (2017) } \\
\text { Indonesian } \\
\text { (9) }\end{array}$ & 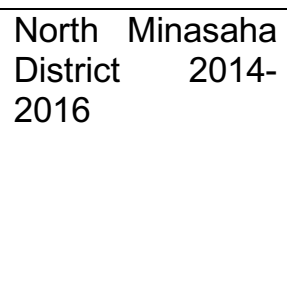 & $\begin{array}{l}\text { Temperature, } \\
\text { humidity, wind } \\
\text { speed, rainfall } \\
\text { and number of } \\
\text { days with rain }\end{array}$ & $\begin{array}{l}\text { Case } \\
\text { counts }\end{array}$ & $\begin{array}{l}\text { - Quantitative by } \\
\text { using an } \\
\text { ecology study } \\
\text { design } \\
\text { - Correlation test } \\
\text { - Linear } \\
\text { regression }\end{array}$ & $\begin{array}{l}\text { - A positive correlation was found } \\
\text { between temperature, humidity, } \\
\text { wind speed and dengue incidence } \\
\text { - Rainfall and number of day rain } \\
\text { were not associated with dengue } \\
\text { incidence }\end{array}$ & - A three-year short study period \\
\hline $\begin{array}{l}\text { Tomia et } \\
\text { al. (2016) } \\
\text { Bahasa } \\
\text { Indonesian } \\
(10)\end{array}$ & $\begin{array}{ll}\text { Ternate } & \text { City } \\
\text { 2007-2014 } & \end{array}$ & $\begin{array}{l}\text { Rainfall, } \\
\text { temperature and } \\
\text { humidity }\end{array}$ & $\begin{array}{l}\text { The } \\
\text { monthly } \\
\text { incidenc } \\
\text { e of } \\
\text { dengue }\end{array}$ & $\begin{array}{l}\text {-Pearson } \\
\text { correlation }\end{array}$ & $\begin{array}{l}\text { - Temperature and dengue incidence } \\
\text { were found correlate } \\
\text { - Rainfall and humidity were not } \\
\text { associated with dengue incidence }\end{array}$ & $\begin{array}{l}\text { - } \quad \text { Employed correlation } \\
\text { - } \\
\text { charded other variables such as habitat } \\
\text { community participation on breeding } \\
\text { site habitat cleaning movement (PSN) } \\
\text { - } \quad \text { Lag times of climatic factors were } \\
\text { analysed }\end{array}$ \\
\hline $\begin{array}{l}\text { Kesetyanin } \\
\text { gsih et al. } \\
(2017) \\
\text { English } \\
(11)\end{array}$ & $\begin{array}{l}\text { Sleman District } \\
2008-2013\end{array}$ & $\begin{array}{l}\text { Monthly } \\
\text { minimum- } \\
\text { maximum } \\
\text { temperature }\end{array}$ & $\begin{array}{l}\text { Monthly } \\
\text { incidenc } \\
\text { e of } \\
\text { dengue }\end{array}$ & $\begin{array}{l}\text {-Linear } \\
\text { regression }\end{array}$ & $\begin{array}{l}\text { - Temperature variability was found to } \\
\text { be associated with dengue } \\
\text { incidence }\end{array}$ & $\begin{array}{l}\text { - The only temperature included } \\
\text { - Explaining other factor such as host } \\
\text { factors and the environmental factors }\end{array}$ \\
\hline $\begin{array}{l}\text { Pakaya, } \\
\text { Ririn } \\
(2015) \\
\text { English } \\
(12)\end{array}$ & $\begin{array}{l}\text { Limboto, } \\
\text { Gorontalo 2012- } \\
2015\end{array}$ & $\begin{array}{l}\text { Precipitation, } \\
\text { temperature, } \\
\text { humidity and wind } \\
\text { speed }\end{array}$ & $\begin{array}{l}\text { Case } \\
\text { counts }\end{array}$ & $\begin{array}{l}\text {-Cross sectional } \\
\text {-Spearman } \\
\text { correlation } \\
\text { - Poisson } \\
\text { regression } \\
\text {-GIS }\end{array}$ & $\begin{array}{l}\text { - The association between humidity } \\
\text { and dengue incidence was found to } \\
\text { be significantly negative }\end{array}$ & - A four-years short study period \\
\hline Hasannah & Jakarta & Temperature, & Case & - Descriptive with & - Strong correlation was found & - Relative long study period \\
\hline
\end{tabular}




\begin{tabular}{|c|c|c|c|c|c|c|}
\hline $\begin{array}{l}\text { \& Dewi } \\
\text { Susanna } \\
\text { (2019) } \\
\text { English } \\
\text { (13) }\end{array}$ & 2016 & $\begin{array}{l}\text { rainfall, and } \\
\text { humidity }\end{array}$ & counts & $\begin{array}{l}\text { ecology study } \\
\text { design } \\
\text {-Correlation test }\end{array}$ & $\begin{array}{l}\text { between humidity and dengue } \\
\text { incidence } \\
\text { - -Medium correlation was found } \\
\text { between temperature and dengue } \\
\text { incidence } \\
\text { - Rainfall had weak correlation to } \\
\text { dengue incidence }\end{array}$ & \\
\hline $\begin{array}{l}\text { Kesetyanin } \\
\text { gsih et al. } \\
\text { (2018) } \\
\text { English } \\
(14)\end{array}$ & $\begin{array}{l}\text { Sleman District } \\
2008-2013\end{array}$ & $\begin{array}{l}\text { Humidity, land } \\
\text { cover, altitude, } \\
\text { rainfall and } \\
\text { temperature }\end{array}$ & $\begin{array}{l}\text { Monthly } \\
\text { incidenc } \\
\text { e of } \\
\text { dengue }\end{array}$ & $\begin{array}{l}\text {-Spatial test } \\
\text {-Spearmen } \\
\text { correlation test } \\
\text {-Pearson } \\
\text { correlation }\end{array}$ & $\begin{array}{l}\text { - Humidity has medium correlation to } \\
\text { dengue incidence } \\
\text { - Land cover, altitude, rainfall had } \\
\text { weak correlation with dengue } \\
\text { incidence } \\
\text { - Temperature was not associated } \\
\text { with dengue incidence } \\
\text { - All climate parameter did not } \\
\text { influence dengue incidence in } \\
\text { sporadic area }\end{array}$ & - Case number per month was absence \\
\hline $\begin{array}{l}\text { Tosepu et } \\
\text { al. (2018) } \\
\text { English } \\
\text { (15) }\end{array}$ & $\begin{array}{l}\text { Kendari, } \\
\text { Southeast } \\
\text { Sulawesi 2010- } \\
2015\end{array}$ & $\begin{array}{l}\text { Temperature, } \\
\text { rainfall and } \\
\text { humidity }\end{array}$ & $\begin{array}{l}\text { Monthly } \\
\text { incidenc } \\
\text { e of } \\
\text { dengue }\end{array}$ & $\begin{array}{l}\text {-Spearmen test } \\
\text {-Time-series } \\
\text { Poisson } \\
\text { regression } \\
\text { multivariate }\end{array}$ & $\begin{array}{l}\text { - Temperature has positive } \\
\text { association with dengue incidence } \\
\text { - Rainfall did not associated with } \\
\text { dengue incidence } \\
\text { - Humidity did not associated with } \\
\text { dengue incidence }\end{array}$ & $\begin{array}{l}\text { - Geographical conditions and behaviour } \\
\text { were explained }\end{array}$ \\
\hline $\begin{array}{l}\text { Tang et al. } \\
\text { (2019) } \\
\text { English } \\
\text { (16) }\end{array}$ & $\begin{array}{l}\text { Surabaya } \\
2009-2017\end{array}$ & $\begin{array}{l}\text { Temperature } \\
\text { average, rainfall } \\
\text { and humidity }\end{array}$ & $\begin{array}{l}\text { Monthly } \\
\text { incidenc } \\
\text { e of } \\
\text { dengue }\end{array}$ & $\begin{array}{l}\text {-One-Sample } \\
\text { Kolmogorov } \\
\text { Smirnov Test } \\
\text { - } \quad \text { Spearman } \\
\text { correlation }\end{array}$ & $\begin{array}{l}\text { - Rainfall and humidity were } \\
\text { associated to dengue incidence } \\
\text { - Temperature average did not } \\
\text { associate with dengue incidence }\end{array}$ & $\begin{array}{l}\text { - One city was included } \\
\text { - Difficult to observe the influence of } \\
\text { temperature because of the lack of } \\
\text { seasonal variation of temperature in } \\
\text { Surabaya } \\
\text { - Lack of mosquito data }\end{array}$ \\
\hline $\begin{array}{l}\text { Setiawati, } \\
\text { et al. } \\
(2017)\end{array}$ & $\begin{array}{l}\text { Medan } \\
2016\end{array}$ & $\begin{array}{l}\text { Average } \\
\text { temperature, } \\
\text { max-min }\end{array}$ & $\begin{array}{l}\text { Case } \\
\text { counts }\end{array}$ & $\begin{array}{l}\text {-Compile data } \\
\text { base } \\
\text {-GAM model }\end{array}$ & $\begin{array}{l}\text { - Rainfall, humidity, rainfall, maximum } \\
\text { temperature influenced dengue } \\
\text { incidence }\end{array}$ & - Several statistical methods were applied \\
\hline
\end{tabular}


Epidemiology and Society Health Review $\mid \boldsymbol{E S H R}$

\begin{tabular}{|c|c|c|c|c|c|c|}
\hline $\begin{array}{l}\text { English } \\
\text { (17) }\end{array}$ & & $\begin{array}{l}\text { temperature, } \\
\text { relative humidity, } \\
\text { precipitation }\end{array}$ & & $\begin{array}{l}\text {-Design } \\
\text { vulnerability \& } \\
\text { Index Generate in GIS }\end{array}$ & $\begin{array}{l}\text { - Climate variability influenced } 74.8 \% \\
\text { of dengue incidence }\end{array}$ & \\
\hline $\begin{array}{l}\text { Ishak et al. } \\
\text { (2018) } \\
\text { English } \\
(18)\end{array}$ & $\begin{array}{l}\text { Banjarmasin, } \\
\text { South } \\
\text { Kalimantan } \\
\text { 2012-2016 }\end{array}$ & $\begin{array}{l}\text { Temperature, } \\
\text { humidity, wind } \\
\text { speed, rainfall }\end{array}$ & $\begin{array}{l}\text { Monthly } \\
\text { incidenc } \\
\text { e of } \\
\text { dengue }\end{array}$ & $\begin{array}{l}\text { - Quantitative } \\
\text { descriptive with } \\
\text { ecological time } \\
\text { trend } \\
\text { - Path analysis }\end{array}$ & $\begin{array}{l}\text { - the only variable that shown positive } \\
\text { correlation between dengue } \\
\text { incidence and rainfall }\end{array}$ & - Relative short study period \\
\hline $\begin{array}{l}\text { Astuti et al. } \\
\text { (2019) } \\
\text { English } \\
\text { (19) }\end{array}$ & $\begin{array}{l}\text { Cirebon, West } \\
\text { Java 2011-2017 }\end{array}$ & $\begin{array}{l}\text { Rainfall, } \\
\text { temperature, } \\
\text { humidity and } \\
\text { NDVI }\end{array}$ & $\begin{array}{l}\text { Monthly } \\
\text { incidenc } \\
\text { e of } \\
\text { dengue }\end{array}$ & $\begin{array}{l}\text {-Spearman } \\
\text { correlation } \\
\text {-Poisson (GLM) } \\
\text {-Spatial analysis } \\
\text {-Time series } \\
\text { (decomposition } \\
\text { analysis with } \\
\text { STL) Moran's I } \\
- \text { analysis } \\
\text { - LISA analysis }\end{array}$ & $\begin{array}{l}\text { - Rainfall, temperature and humidity } \\
\text { were associated to dengue } \\
\text { incidence }\end{array}$ & $\begin{array}{l}\text { - One city was included } \\
\text { - Several statistical methods were applied } \\
\text { - Ssocioeconomic factors were } \\
\text { Considered } \\
\text { - Spatial-temporal analysis }\end{array}$ \\
\hline $\begin{array}{l}\text { Tosepu et } \\
\text { al. (2018) } \\
\text { English } \\
(20)\end{array}$ & $\begin{array}{l}\text { Kolaka, } \\
\text { Southeast } \\
\text { Celebes 2010- } \\
2015\end{array}$ & $\begin{array}{l}\text { Rainfall, } \\
\text { humidity, } \\
\text { temperature } \\
\text { average, } \\
\text { minimum- } \\
\text { maximum } \\
\text { temperature }\end{array}$ & $\begin{array}{l}\text { Monthly } \\
\text { incidenc } \\
\text { e of } \\
\text { dengue }\end{array}$ & $\begin{array}{l}\text {-Regression } \\
\text { linear } \\
\text {-Spearman } \\
\text { correlation } \\
\text {-Poisson } \\
\text { distribution }\end{array}$ & $\begin{array}{l}\text { - All climate variables investigated } \\
\text { were associated with dengue } \\
\text { incidence }\end{array}$ & $\begin{array}{l}\text { Various meteorological variables were } \\
\text { considered }\end{array}$ \\
\hline
\end{tabular}


Epidemiology and Society Health Review $\mid E S H R$

\begin{tabular}{|c|c|c|c|c|c|c|}
\hline $\begin{array}{l}\text { Haryanto. } \\
\text { Budi } \\
\text { (2016) } \\
\text { English } \\
\text { (21) }\end{array}$ & $\begin{array}{l}\text { Indonesia 1980- } \\
2010\end{array}$ & $\begin{array}{l}\text { Temperature and } \\
\text { rainfall }\end{array}$ & $\begin{array}{l}\text { Case } \\
\text { counts }\end{array}$ & $\begin{array}{l}\text {-Ecological } \\
\text { time-series } \\
\text { study design } \\
\text {-Vulnerability } \\
\text { Analysis of the } \\
\text { IPCC } 2001 \\
\text {-Correlation and } \\
\text { regression } \\
\text { analysis } \\
\text {-GIS }\end{array}$ & $\begin{array}{l}\text { - High intensity of rainfall had } \\
\text { weak association in } 11 \text { districts in } \\
\text { Indonesia } \\
\text { - Rainfall and temperature in other } \\
\text { city were not associated with } \\
\text { dengue incidence }\end{array}$ & $\begin{array}{l}\text { Long-term data from a thirty years } \\
\text { period }\end{array}$ \\
\hline
\end{tabular}




\section{Epidemiology and Society Health Review $\mid \boldsymbol{E S H R}$}

The impact of rainfall to dengue incidence was recognised in most of the analysed research (13-21). Research in Jakarta by using 9 years of data set (2008-2016) shows dengue incidence was significantly associated with rainfall about $254-667 \mathrm{~mm}$ then followed by high dengue incidence in 0-3 month in the beginning of the year (13). Temporal relationship between rainfall and dengue incidence was identified as linear between the increase of $10 \mathrm{~mm}$ of the rainfall and $1 \%$ increase of dengue incidence in three months (23). In another research, it was mentioned that the increase of the rainfall led to the increase of the mosquito breeding place (9). While in North Minahasa and Ternate City, rainfall and dengue were not associated (9),(10). According to PLUM model aimed to evaluate the high rainfall intensity and larva flush from the breeding place, it shows that rainfall and dengue were not associated (24). High of precipitation makes larvae transported and sometimes dies due to continues water stream and the absence of puddle for the mosquito breeding site (9).

Humidity sometimes caused by high intensity of rainfall, make the environment suitable for Aedes life (11),(13). The relationship between humidity and dengue incidence occurred in some areas of Indonesia was reported by some researches (9),(12),(13),(14),(16),(17),(19),(20) , while the rest of the research did not involve humidity as research variable. A research in Jakarta shows that humidity was a meteorological variable that is strongly associated with dengue incidence compared to temperature and rainfall (13). Likewise, a research in Singapore reported that humidity was the most climate variable that influenced dengue incidence (25). Humidity is a suitable condition for mosquito reproduction. High humidity affects the high dengue incidence as occurred in North Minahasa. In that place, dengue incidence was high in January 2015 in $89 \%$ of humidity (9). When humidity is lower than $60 \%$ it will shorten the mosquito age; consequently, mosquito cannot continue its reproduction cycle (18).

In North Minahasa, the relationship between wind speed and dengue transmission was identified. It could be seen from the increase of dengue case along with the decrease of wind speed 1 knot in May 2015. Wind speed influences the mosquitos flight range; accordingly, the decrease in wind speed is followed by the dengue incidence (9). However, research in Limboto Sub-district and Banjarmasin City reported that there was no relationship between wind speed and dengue incidence (12),(18).

\section{CONCLUSIONS}

The impact of climate change and dengue incidence have been discussed on this review. Protection and adaptation to this situation are critical to overcoming dengue risk in society. Early warning system (EWS) development based on climate information can be one alternative solution to inform the community that when climate variables are changing it would potentially influence the dengue transmission. Holistic work by involving the associated office such as Meteorological, Climatological and Geophysical Agency (BMKG) is recommended. EWS based on climatic information has been done in Jakarta province and expected to be extended 
in other regions in Indonesia. This effort aimed to give information to the population according to the present climate situation. Accordingly, there would be follow up actions such as epidemiological assessment, counselling, environment refinement, selective and mass larvaciding, and fogging (26). Other efforts such as mosquito's breeding site elimination or called PSN and health services should be improved and scaled up

\section{AUTHORS' CONTRIBUTION}

SS Designed the study, writing the manuscript. FF conducted a literature search and writing the result.

\section{FUNDING}

This research did not receive external funding

\section{Conflict of interest}

There are no conflicts of interest

\section{REFERENCES}

1. IPCC. Summary for Policymakers. In: Global warming of $1.5^{\circ} \mathrm{C}$. An IPCC Special Report on The Impacts of Global Warming [Internet]. 2018. 32 p. Available from: https://www.ipcc.ch/

2. Mordecai EA, Cohen JM, Evans M V., Gudapati P, Johnson LR, Lippi CA, et al. Detecting the Impact of Temperature on Transmission of Zika, Dengue, and Chikungunya Using Mechanistic Models. PLoS Negl Trop Dis. 2017;11(4):118.

3. Ryan SJ, Carlson CJ, Mordecai EA, Johnson LR. Global Expansion and Redistribution of Aedes-borne Virus Transmission Risk with Climate Change. PLoS Negl Trop Dis. 2018;13(3):1-20.

4. Hairiah K, Rahayu S, Suprayogo D, Prayogo C. Perubahan iklim: Sebab dan Dampaknya Terhadap Kehidupan. 2016. 1-40 p.

5. Badan Meteorologi dan Geofisika (BMKG). Ekstrem Perubahan Iklim [Internet]. BMKG. 2019. Available from: https://www.bmkg.go.id/iklim/?p=ekstremperubahan-iklim

6. Karyanti MR, Uiterwaal CSPM, Kusriastuti R, Hadinegoro SR, Rovers MM, Heesterbeek $\mathrm{H}$, et al. The Changing Incidence of Dengue Haemorrhagic Fever in Indonesia: A 45-year Registry-Based Analysis. BMC Infect Dis. 2014;14(1):1-7.

7. Haryanto B. Climate Change and Human Health Scenario in South and Southeast Asia. 2016;(November).

8. Kementrian Kesehatan RI. InfoDatin Situas Demam Berdarah Dengue. 2018.

9. Lasut RA, Kaunang WPJ, Kalesaran AFC. Hubungan Variabilitas Iklim Dengan Kejadian Demam Berdarah Dengue (Dbd) Di Kabupaten Minahasa Utara Tahun 2014-2016. Fak Kesehat Masy Univ Sam Ratulangi Manad. 2016;9(3):1-12. 


\section{Epidemiology and Society Health Review $\mid \boldsymbol{E S H R}$}

10. Tomia A, Hadi U, Soviani S, Retnani E. Kejadian Demam Berdarah Dengue (DBD) Berdasarkan Faktor Iklim di Kota Ternate. Media Kesehat Masy Indones Univ Hasanuddin. 2016;12(4):241-9.

11. Kesetyaningsih TW, Andarini S, Sudarto S, Pramoedyo H. The MinimumMaximum Weather Temperature Difference Effect on Dengue Incidence in Sleman Regency of Yogyakarta, Indonesia. Walailak J Sci Technol. 2018;15(5):387-96.

12. Pakaya R. Spatial Analysis and Environmental Factors Associated Against Case of Dengue Hemorrhagic Fever ( Dhf ) in Limboto District , Gorontalo. Public Heal Gorontalo Univ. 2015;45-55.

13. Hasanah, Susanna D. Weather Implication for Dengue Fever in Jakarta, Indonesia 2008-2016. KnE Life Sci. 2019;4(10):184.

14. Kesetyaningsih TW, Andarini S, Sudarto, Pramoedyo H. Determination of Environmental Factors Affecting Dengue Incidence in Sleman District, Yogyakarta, Indonesia. African J Infect Dis. 2018;12(Special Issue 1):13-25.

15. Tosepu R, Tantrakarnapa K, Nakhapakorn K, Worakhunpiset S. Climate Variability and Dengue Hemorrhagic Fever in Southeast Sulawesi Province, Indonesia. Environ Sci Pollut Res. 2018;25(15):14944-52.

16. Tang SCN, Rusli M, Lestari P. Climate Variability and Dengue Hemorrhagic Fever in Surabaya, East Java, Indonesia. Arlangga Unversity [Internet]. 2018;(December). Available from: https://www.preprints.org/manuscript/201812.0206/v1

17. Setiawati MDKF. The Influence of Climate Variables on Dengue in Singapore. Int J Environ Health Res [Internet]. 2011;21(6):415-26. Available from: http://ovidsp.ovid.com/ovidweb.cgi?T=JS\&PAGE=reference\&D=emed10\&NEW $S=N \& A N=2012050378$

18. Ishak NIK. The Effect of Climate Factors for Dengue Hemorrhagic Fever in Banjarmasin City, South Kalimantan Province, Indonesia, 2012-2016. Public Heal Indones. 2018;4(3):121-8.

19. Astuti EP, Dhewantara PW, Prasetyowati H, Ipa M, Herawati C, Hendrayana K. Paediatric Dengue Infection in Cirebon, Indonesia: A Temporal and Spatial Analysis of Notified Dengue Incidence to Inform Surveillance. Parasites and Vectors [Internet]. 2019;12(1):1-12. Available from: https://doi.org/10.1186/s13071-019-3446-3

20. Tosepu R, Tantrakarnapa K, Worakhunpiset S, Nakhapakorn K. Climatic Factors Influencing Dengue Hemorrhagic Fever in Kolaka District, Indonesia. Environ Nat Resour J. 2018;16(2):1-10.

21. Haryanto B. Dengue Hemorrhagic Fever Vulnerability to Climate in Indonesia: Assessment, Projection, and Mapping. Univ Indones. 2018;(October 2014).

22. Goindin D, Delannay C, Ramdini C, Gustave J, Fouque F. Parity and Longevity of Aedes aegypti According to Temperatures in Controlled Conditions and Consequences on Dengue Transmission Risks. PLoS One. 2015;10(8):1-21.

23. Silva FD, Santos AM dos, Corrêa R da GCF, Caldas A de JM. Temporal 
Relationship Between Rainfall, Temperature and Occurrence of Dengue Cases in São Luís, Maranhão, Brazil. Cien Saude Colet. 2016;21(2):641-6.

24. Benedum CM, Seidahmed OME, Eltahir EAB, Markuzon N. Statistical Modeling of The Effect of Rainfall Flushing on Dengue Transmission in Singapore. PLoS Negl Trop Dis. 2018;12(12):1-18.

25. Xu HY, Fu X, Lee LKH, Ma S, Goh KT, Wong J, et al. Statistical Modeling Reveals the Effect of Absolute Humidity on Dengue in Singapore. PLoS Negl Trop Dis. 2014;8(5).

26. Dewi MK. Informasi Peringatan Dini DBD Berbasis Iklim. www.bmkg.go.id. 2018. 